\title{
Quinolinium Structure as Labeled Biomarkers
}

\author{
Nadezhda Shchepina ${ }^{*}$, Viktor Avrorin², Gennadii Badun ${ }^{3}$, Galina Alexandrova1, \\ Irina Agafonova', Nina Popova1 \\ ${ }^{1}$ Laboratory of Radiochemistry, Natural Sciences Institute of Perm State University, Perm, Russia \\ ${ }^{2}$ Chemistry Department, St. Petersburg State University, St. Petersburg, Russia \\ ${ }^{3}$ Radiochemistry Department, M. V. Lomonosov Moscow State University, Moscow, Russia \\ Email: ${ }^{*}$ neshchepina@mail.ru
}

Received 12 May 2014; revised 13 June 2014; accepted 27 June 2014

Copyright (C) 2014 by authors and Scientific Research Publishing Inc.

This work is licensed under the Creative Commons Attribution International License (CC BY).

http://creativecommons.org/licenses/by/4.0/

(c) (i) Open Access

\section{Abstract}

In this study the compatible chemical and biological investigations of several N-phenylquinolinium derivatives have been carried out in order to find the most perspective quinolinium structures for the nuclear-chemical synthesis of tritium labeled biomarkers.

\section{Keywords}

N-Phenylquinolinium Compounds, Biological Activity, Antimicrobial and Antimycotic Action, Perspective Tritium Labeled Biomarkers, Nuclear-Chemical Synthesis

\section{Introduction}

It is well-known that nitrogen-containing six-membered heterocycles are extremely important ring systems of biological investigations [1] [2]. Drug efficiency greatly depends on aqueous solubility and permeability through the cell membranes and this results in extensive application of lipophilic quaternary pyridinium derivatives in medicine [3]-[5]. Biological investigations reveal that the activity of pyridinium derivatives mainly depended on the structure of substituents on the heterocyclic ring [6]-[8]. Derivatives of benzopyridine-quinolinium salts open new horizons in drug chemistry [9]-[13]. In the 21st century, interest in new synthesis of perspective biologically active quinolinium structures even will increase [14]-[20].

$\mathrm{N}$-phenyl substituted quinolinium and quinaldinium salts due to their structure may possess antibacterial, antifungal and anti-cancer activity. Unfortunately synthesis of such derivatives is very difficult and complex due to the lack of direct phenylation of nitrogen atom [21] [22]. Our elaborated nuclear-chemical synthetic method us-

\footnotetext{
${ }^{*}$ Corresponding author.
}

How to cite this paper: Shchepina, N., Avrorin, V., Badun, G., Alexandrova, G., Agafonova, I. and Popova, N. (2014) Quinolinium Structure as Labeled Biomarkers. Open Journal of Synthesis Theory and Applications, 3, 21-26.

http://dx.doi.org/10.4236/ojsta.2014.33004 
ing free nucleogenic phenyl cations generated by tritium $\beta$-decay allows the one-step synthesis of hardly available N-phenyl-substituted heterocyclic compounds [23]-[27].

In this study we have carried out compatible chemical and biological investigations in order to find the most appropriate structures for the nuclear-chemical synthesis of tritium labeled biomarkers.

\section{Experimental}

\subsection{Synthesis of Quinolinium Compounds}

The specificity of nuclear-chemical synthesis requires availability of unlabeled isotopic carriers. For this purpose we have synthesized different $\mathrm{N}$-phenyl substituted quinolinium derivatives by known literature chemical methods.

All reagents and solvents were obtained from commercial suppliers.

\subsubsection{N-Phenylquinaldinium Salts}

The cyclization of secondary aromatic amines with carbonyl compounds provides a suitable method for the synthesis of N-arylquinolinium salts [28]. Using the Doebner-Miller reaction to diarylamines, Pilyugin and Krainer [29] developed a method for the preparation of quaternary N-phenylquinaldinium salts (Scheme 1). Mp $159^{\circ} \mathrm{C}-160^{\circ} \mathrm{C}$ (recrystallization from $\mathrm{H}_{2} \mathrm{O}$ ) [30].

\subsubsection{N-Phenyllepidinium Salts}

N-Phenyllepidinium perchlorate was obtained by a modification of the Beyer reaction using diphenylamine and formalin in presence of acetone and nitrobenzene according to the procedure by Pilyugin [31] (Scheme 2). Recrystallization from water gave almost colorless crystals, $\mathrm{mp} 172^{\circ} \mathrm{C}-173^{\circ} \mathrm{C}\left(\mathrm{mp} 172^{\circ} \mathrm{C}\right)[31]$.

\subsubsection{N-Phenylbenzo[f]quinaldinium Salts}

The reference inactive markers $\mathrm{N}$-phenylbenzo[f]quinaldinium salts were synthesized by a modified literature procedure [32] [33] via cyclization of phenyl- $\beta$-naphthylamine and paraldehyde (Scheme 3):<smiles>CC(C)c1ccc2c(ccc(-c3ccccc3)[n+]2-c2ccccc2)c1</smiles>

Scheme 1. Synthesis of N-phenylquinaldinium perchlorate.

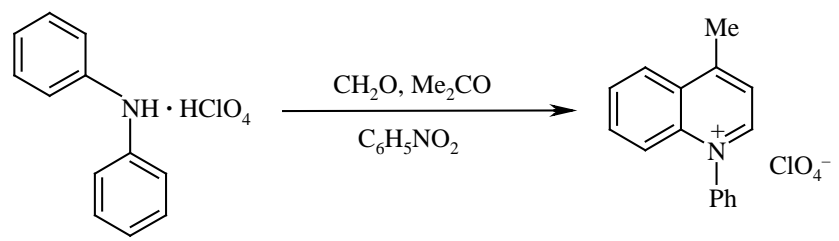

Scheme 2. Synthesis of N-phenyllepidinium perchlorate.

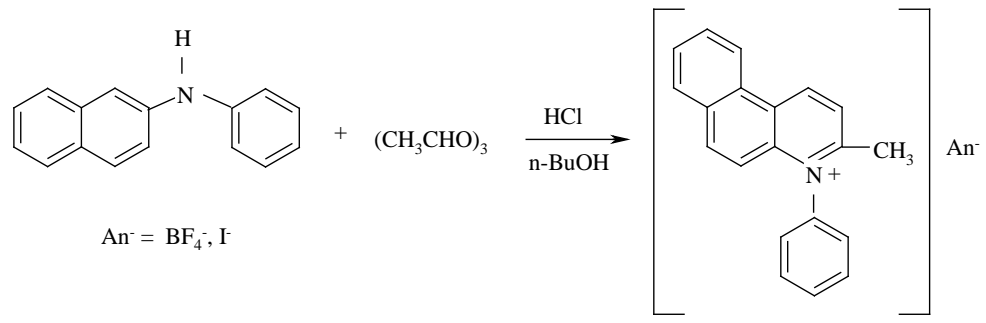

Scheme 3. Synthesis of N-phenylbenzo[f]quinaldinium salts. 
1) N-Phenylbenzo[f]quinaldinium Iodide

Treatment of the reaction mixture with a saturated solution of KI gave N-phenylbenzo[f]quinaldinium iodide. The salt was isolated by crystallization from $50 \%$ acetic acid as needle-shaped crystals of $\mathrm{mp} 196^{\circ} \mathrm{C}-197^{\circ} \mathrm{C}$ (mp $\left.196^{\circ} \mathrm{C}-197^{\circ} \mathrm{C}\right)[34][35]$.

2) N-Phenylbenzo[f]quinaldinium Tetrafluoroborate

$\mathrm{N}$-Phenylbenzo[f]quinaldinium tetrafluoroborate was prepared analogously only using tetrafluoroboric acid (40\%) or saturated sodium tetrafluoroborate solution as the precipitant, $\mathrm{mp} 135^{\circ} \mathrm{C}-136^{\circ} \mathrm{C}$.

\subsection{General Procedure for the Nuclear-Chemical Synthesis}

Nuclear-chemical synthesis was carried out in sealed glass ampoules containing the source of the phenyl cations (tritiated benzene), the nucleophile of interest and with an inorganic salt to serve as a stabilizing anion $\left(\mathrm{KBF}_{4}, \mathrm{KI}\right.$, $\mathrm{KClO}_{4}$ ). The benzene/substrate ratio was not less than $1: 10^{3}$, in order to reduce the amount of the side products. The ampule was sealed and maintained for 1 - 2 months to accumulate the nuclear-chemical synthesis products. Since the radioactive decay does not depend on the reaction conditions such as temperature and pressure, the accumulation of tritium-labeled compounds was carried out at $-18^{\circ} \mathrm{C}$ in order to prevent the formation of thermal decomposition products. The ampule was opened and the contents were transferred to a special flask. Benzene $(0.5 \mathrm{ml})$ and acetone solution of inactive $\mathrm{N}$-phenylsubstituted onium carrier $(0.5 \mathrm{ml}, 1 \mathrm{mg} / \mathrm{ml})$ were then added. Unreacted tritiated benzene was distilled off in vacuum. Then acetone $(0.5 \mathrm{ml})$ was added to the dry residue and $5-\mu l$ samples were taken for thin-layer chromatographic separation of the labeled products. Radioactivity of the sorbent layer was measured using a scintillation spectrometer RackBeta 1215 (LKB Wallac, Finland).

\subsection{Synthesis of Ditritiated Benzene}

The synthesis of double tritium labeled benzene was carried out in a vacuum by catalytic dehalogenation of $p$-dibromobenzene with gaseous tritium [36]. The purity of the prepared benzene sample was at least $99 \%$. The specific activity of double tritiated benzene was $58 \mathrm{Ci} / \mathrm{mmol}$. A hexane solution of the tritium-labeled benzene was used without a carrier. The bulk specific activity of the hexane solution was $1 \mathrm{Ci} / \mathrm{ml}$. Such dilution was important to prevent radiolysis and the formation of side products.

\subsection{Biological Research}

Antimicrobial and antifungal activity was studied by the double serial dilution method [37]. The opportunistic pathogenic cultures were strains of Staphylococcus aureus-906, Escherichia coli-1257 and fungus Candida albicans-264/624 from L. A. Tarasevich GOSNII for Standardization and Control of Medical and Biological Preparations (Moscow). Candida krusei were the hospital strains, isolated from the hospital environment. Initial dilutions of the pathogens were prepared using an optical standard from a daily agar culture. The microbe loading was $2.5 \times 10^{5}$ microbes per ml. The combined microbe suspension and drug solution (diluted in DMSO) was placed in the growth medium. Results were recorded after 20 hours for bacteria or 48 hours for fungus (MIC) and 7 days (MBC) at $37^{\circ} \mathrm{C}$ (thermostat). Antimicrobial bacteriostatic (MIC) and bactericidal (MBC) activities were estimated from the minimum active concentration. The maximum test concentration of a new compound was $1.000 \mathrm{mg} / \mathrm{ml}$.

\section{Results and Discussion}

The results of biological activity of the investigated N-phenylquinaldinium derivatives are presented in the Table 1.

Carried out biological investigations revealed that a substituent (methyl group and annelated benzene ring in the quinolinium compound) together with the stabilizing anion had high influence on the level of obtained biological activity (both on MIC and MBC). The most active was N-phenylbenzo[f]quinaldinium tetrafluoroborate that showed high antimicrobial activity towards St. Aureus and antimycotic action against Candida sorts.

\section{Conclusion}

Further research in the field of nuclear-chemical synthetic methods will be focused on the preparation of tritium 
Table 1. Results of biological activity of the investigated N-phenylquinaldinium derivatives.

\begin{tabular}{|c|c|c|c|c|c|c|c|c|}
\hline \multirow{2}{*}{ Compound } & \multicolumn{2}{|c|}{ E. coli } & \multicolumn{2}{|c|}{ St. aureus } & \multicolumn{2}{|c|}{$\begin{array}{l}\text { Candida } \\
\text { albicans }\end{array}$} & \multicolumn{2}{|c|}{$\begin{array}{c}\text { Candida } \\
\text { crusei }\end{array}$} \\
\hline & $\begin{array}{c}\mathrm{MIC} \\
(\mathrm{mcg} / \mathrm{ml})\end{array}$ & $\begin{array}{c}\mathrm{MBC} \\
(\mathrm{mcg} / \mathrm{ml})\end{array}$ & $\begin{array}{c}\text { MIC } \\
(\mathrm{mcg} / \mathrm{ml})\end{array}$ & $\begin{array}{c}\mathrm{MBC} \\
(\mathrm{mcg} / \mathrm{ml})\end{array}$ & $\begin{array}{c}\text { MIC } \\
(\mathrm{mcg} / \mathrm{ml})\end{array}$ & $\begin{array}{c}\mathrm{MBC} \\
(\mathrm{mcg} / \mathrm{ml})\end{array}$ & $\begin{array}{c}\text { MIC } \\
(\mathrm{mcg} / \mathrm{ml})\end{array}$ & $\begin{array}{c}\mathrm{MBC} \\
(\mathrm{mcg} / \mathrm{ml})\end{array}$ \\
\hline
\end{tabular}

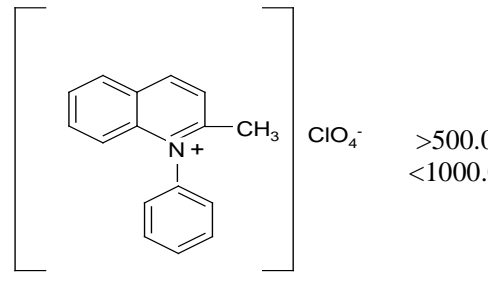

N-phenylquinaldinium perchlorare<smiles>C1CCCCC1</smiles><smiles>CCCCC(=O)CC</smiles>

N-phenyllepidinium perchlorare<smiles>Cc1ccc2c3ccccc3ccc2[n+]1-c1ccccc1</smiles>

N-phenylbenzo[f]quinaldinium tetrafluoroborate<smiles>Cc1ccc2c3ccccc3ccc2[n+]1-c1ccccc1</smiles>

N-phenylbenzo[f]quinaldinium iodide

Standard chinosolum

1000.0

Standard nitroxolinum (5-nitro-8-oxiquinoline)

labeled N-phenylbenzo[f]quinaldinium structures as effective radio markers and also investigations on mechanism of drug action. 


\section{Acknowledgements}

This work was carried out under the support of grant (basic part) of Russian Ministry of Science and Education.

\section{References}

[1] Pozharskii, A.F., Soldatenkov, A.T. and Katritzky, A.R. (1997) Heterocycles in Life and Society. John Wiley \& Sons Ltd., New York.

[2] Carey, J.S., Laffan, D., Thomson, C. and Williams, M.T. (2006) Analysis of the Reactions Used for the Preparation of Drug Candidate Molecules. Organic and Biomolecular Chemistry, 4, 2337-2347. http://dx.doi.org/10.1039/b602413k

[3] Zhao, T. and Sun, G. (2008) Hydrophobicity and Antimicrobial Activities of Quaternary Pyridinium Salts. Journal of Applied Microbiology, 104, 824-830. http://dx.doi.org/10.1111/j.1365-2672.2007.03616.X

[4] Laufer, R., Bathori, M., Csermery, T., Petroiani, G., Kuca, K., Toth, N. and Kalasz, H. (2007) LC Determination of Hydrophilicity Parameter of Some Pyridinium Aldoximes. Journal of Liquid Chromatography and Related Technologies, 30, 2337-2344. http://dx.doi.org/10.1080/10826070701451738

[5] Kumar, V. and Malhotra, S.V. (2010) Ionic Liquids as Pharmaceutical Salts: A Historical Perspective. ACS Symposium Series, 1038, 1-12.

[6] Docherty, K. and Kulpa, C.F. (2005) Toxicity and Antimicrobial Activity of Imidazolium and Pyridinium Ionic Liquids. Green Chemistry, 7, 185-189. http://dx.doi.org/10.1039/b419172b

[7] Zhao, T. and Sun, G. (2006) Synthesis and Characterization of Antimicrobial Cationic Surfactants: Aminopyridinium Salts. Journal of Surfactants and Detergents, 9, 325-330. http://dx.doi.org/10.1007/s11743-006-5010-3

[8] Musilek, K., Kusa, K., Jun, D., Dohnal, V. and Dolezal, M. (2005) Synthesis of a Novel Series of Bispyridinium Compounds Bearing a Xylene Linker and Evaluation of Their Reactivation Activity Against Chlorpyyrifos-Inhibited Acetylcholinnesterase. Journal of Enzyme Inhibition and Medicinal Chemistry, 20, 409-415. http://dx.doi.org/10.1080/14756360500179762

[9] Gutsulyak, B.M. (1972) Biological Activity of Quinolinium Salts. Russian Chemical Reviews, 41, 187-202. http://dx.doi.org/10.1070/RC1972v041n02ABEH002038

[10] Sidorchuk, I.I., Stadniichuk, R.F., Tishchenko, E.I. and Bordyakovskaya, L.T. (1978) Antimicrobial Activity of Quaternary Quinolinium Salts. Pharmaceutical Chemistry Journal, 12, 893-895. http://dx.doi.org/10.1007/BF00777632

[11] Voznyak, V.I., Savitskaya, L.G. and Neporadnyi, D.D. (1984) Antimicrobial Activity of Quaternary 4-(P-Dimethylaminostyryl)Quinolinium Salts. Pharmaceutical Chemistry Journal, 18, 561-563.

[12] Cox, O., Jackson, H., Vargas, A., Báez, A., Colón, J.I., González, B.C. and de León, M. (1982) Synthesis and Biological Activity of Benzothiazolo- and Benzoxazolo[3, 2-a]Quinolinium Salts. Journal of Medicinal Chemistry, 25, 13781381. http://dx.doi.org/10.1021/jm00353a020

[13] Hernández, H.J. (1982) Synthesis and Biological Activity of Some Benzoheterazolo (3, 2-a) Quinolinium Salts. Universidad de Puerto Rico, 208.

[14] Joaquin, C.R., Galanakis, D., Piergentili, A., Bhandari, K., Ganellin, C.R., Dunn, P.M. and Jenkinson, D.H. (2000) Synthesis, Molecular Modeling, and Pharmacological Testing of Bis-Quinolinium Cyclophanes: Potent, Non-Peptidic Blockers of the Apamin-Sensitive $\mathrm{Ca}^{2+}$-Activated $\mathrm{K}^{+}$Channel. Journal of Medicinal Chemistry, 43, 420-431. http://dx.doi.org/10.1021/jm9902537

[15] Campos, J.M., Nú-ez, M.C., Sánchez, R.M., Gómez-Vidal, J.A., Rodríguez-González, A., Bá-ez, M., Gallo, M.A., Lacal, J.C. and Espinosa, A. (2002) Quantitative Structure-Activity Relationships for a Series of Symmetrical Bisquaternary Anticancer Compounds. Bioorganic \& Medicinal Chemistry, 10, 2215-2231. http://dx.doi.org/10.1016/S0968-0896(02)00054-8

[16] Barchéchath, S.D., Tawatao, R.I., Corr, M., Carson, D.A. and Cottam, H.B. (2005) Quinolinium Salt as a Potent Inhibitor of Lymphocyte Apoptosis. Bioorganic \& Medicinal Chemistry Letters, 15, 1785-1788. http://dx.doi.org/10.1016/j.bmcl.2005.02.047

[17] Srivani, P. and Sastry, G.N. (2009) Potential Choline Kinase Inhibitors: A Molecular Modeling Study of Bis-Quinolinium Compounds. Journal of Molecular Graphics \& Modelling, 27, 676-688. http://dx.doi.org/10.1016/j.jmgm.2008.10.010

[18] Zayas, B. and Cox, O. (2012) Method for Producing Benzazoloquinolium (BQs) Salts, Using the Composition as Cellular Markers, and Using the Biological Activity of the Composition. US Patent No. 20120129882.

[19] Vélez, C., Cox, O., Rosado-Berrios, C.A., Molina, D., Arroyo, L., Carro, S., Filikov, A., Kumar, V., Malhotra, S.V., Cordero, M. and Zayas, B. (2013) Novel Nitrobenzazolo [3, 2-a] Quinolinium Salts Induce Cell Death through a Mechanism Involving DNA Damage, Cell Cycle Changes, and Mitochondrial Permeabilization. Open Journal of Apopto- 
sis, 2, 13-22. http://dx.doi.org/10.4236/ojapo.2013.22002

[20] Bringmanna, G., Thomale, K., Bischof, S., Schneider, C., Schultheis, M., Schwarz, T., Mollb, H. and Schurigtb, U. (2013) A Novel Leishmania major Amastigote Assay in 96-Well Format for Rapid Drug Screening and Its Use for Discovery and Evaluation of a New Class of Leishmanicidal Quinolinium Salts. Antimicrobial Agents and Chemotherapy, 57, 3003-3011. http://dx.doi.org/10.1128/AAC.02201-12

[21] Pausacker, K.H. (1958) Arylation of Aromatic Compounds. VI. Benzoyl Peroxide with Pyridine and Quinoline. Australian Journal of Chemistry, 11, 200-210. http://dx.doi.org/10.1071/CH9580200

[22] Brody, F. and Ruby, P.R. (1960) Pyridine and Its Derivatives. Part I, In Klingsberg, Ed., Interscience Publishers, Inc., New York.

[23] Shchepina, N.E., Avrorin, V.V., Badun, G.A., Lewis, S.B., Fedoseev, V.M. and Ukhanov, S.E. (2009) The Reaction of Direct Phenylation by Nucleogenic Cations as a Method of Synthesis of Unknown or Complicated Tritium Labeled Compounds. Moscow University Chemistry Bulletin, 64, 244-248. http://dx.doi.org/10.3103/S0027131409050034

[24] Shchepina, N.E., Avrorin, V.V., Badun, G.A., Alexandrova, G.A., Ukhanov, S.E., Fedoseev, V.M. and Boiko, I.I. (2009) Preparation of N-Phenyl-Substituted Quinolinium Derivatives Labeled with Tritium by Chemonuclear Synthesis. Chemistry of Heterocyclic Compounds, 45, 796-801. http://dx.doi.org/10.1007/s10593-009-0359-7

[25] Shchepina, N.E., Avrorin, V.V., Badun, G.A., Fedoseev, V.M. and Lewis, S.B. (2010) New Method for the Synthesis of Difficultly Available Sterically Hindered Tritium-Labeled Pyridinium Derivatives. Chemistry of Heterocyclic Compounds, 46, 547-552. http://dx.doi.org/10.1007/s10593-010-0544-8

[26] Shchepina, N.E., Avrorin, V.V., Badun, G.A., Bumagin, N.A., Lewis, S.B. and Shurov S.N. (2012) Pathways of Ionmolecular Interactions of Nucleogenic Phenyl Cations with the Nucleophilic Centers of Picolines. Organic and Medicinal Chemistry Letters, 2, 14. http://dx.doi.org/10.1186/2191-2858-2-14

[27] Shchepina, N.E., Avrorin, V.V., Alexandrova, G.A., Badun, G.A., Boiko, I.I. and Shurov, S.N. (2013) Investigation of the Phenylation of Methyl-Quinolines Using Tritium-Labeled Nucleogenic Phenyl Cations. Chemistry of Heterocyclic Compounds, 49, 428-434. http://dx.doi.org/10.1007/s10593-013-1264-7

[28] Pilyugin, G.T. and Gutsulyak, B.M. (1963) Advances in the Preparation, Investigation, and Use of Quinolinium Compounds. Russian Chemical Reviews, 32, 167-188. http://dx.doi.org/10.1070/RC1963v032n04ABEH001327

[29] Pilyugin, G.T. and Krainer, Z.Y. (1951) Phenylsubstituted Quinocyanines. Doklady Akademii Nauk, 8, 609-612.

[30] Chernyuk, I.N., Pilyugin, G.T. and Zlochevskaya, A.V. (1970) Studies in the Field of Synthetic Dyes. Chemistry of Heterocyclic Compounds, 4, 236-237. http://dx.doi.org/10.1007/BF00601137

[31] Pilyugin, G.T. and Gutsulyak, B.M. (1959) Studies of Synthetic Dyes: Synthesis of n-Phenyllepidine Perchlorate and Some of Its Transformation. XIV. Zhurnal Obshchei Khimii, 29, 3076-3079.

[32] Pilyugin, G.T. and Opanasenko, E.P. (1952) Synthesis of $\beta$-Naphtoquinaldine Iodinephenilate and Its Transformations. Ukrainskii Khimicheskii Zhurnal (Russian Edition), 18, 625-630.

[33] Shchepina, N.E., Boiko, I.I. and Aleksandrova, G.A. (2011) Synthesis and Antimicrobial Activity of Quaternary N-Aryl-5, 6-benzoquinaldinium Derivatives. Pharmaceutical Chemistry Journal, 45, 159-161. http://dx.doi.org/10.1007/s11094-011-0583-1

[34] Pilyugin, G.T. and Opanasenko, E.P. (1957) Cyandyes. VII. Cyclization of Secondary Aromatic Amines with Vinyl Ethers and Arylquinaldinium Derivatives Formation. Zhurnal Obshchei Khimii, 27, 1015-1018.

[35] Pilyugin, G.T., Gorichok, Ya.O., Gutsulyak, B.M. and Gorichok, S.I. (1965) Researches on Synthetic Dyes. Chemistry of Heterocyclic Compounds, 1, 603-608. http://dx.doi.org/10.1007/BF00472701

[36] Shchepina, N.E., Avrorin, V.V., Badun, G.A., Lewis, S.B. and Ukhanov, S.E. (2012) Preparation of Fused N-Phenylsubstituted Pyridinium Derivatives by Direct Phenylation with Nucleogenic Phenyl Cations. Chemistry of Heterocyclic Compounds, 48, 301-308. http://dx.doi.org/10.1007/s10593-012-0990-6

[37] Pershin, G.N. (1971) Methods of Experimental Chemotherapy. Medgiz, Moscow. 
Scientific Research Publishing (SCIRP) is one of the largest Open Access journal publishers. It is currently publishing more than 200 open access, online, peer-reviewed journals covering a wide range of academic disciplines. SCIRP serves the worldwide academic communities and contributes to the progress and application of science with its publication.

Other selected journals from SCIRP are listed as below. Submit your manuscript to us via either submit@scirp.org or Online Submission Portal.
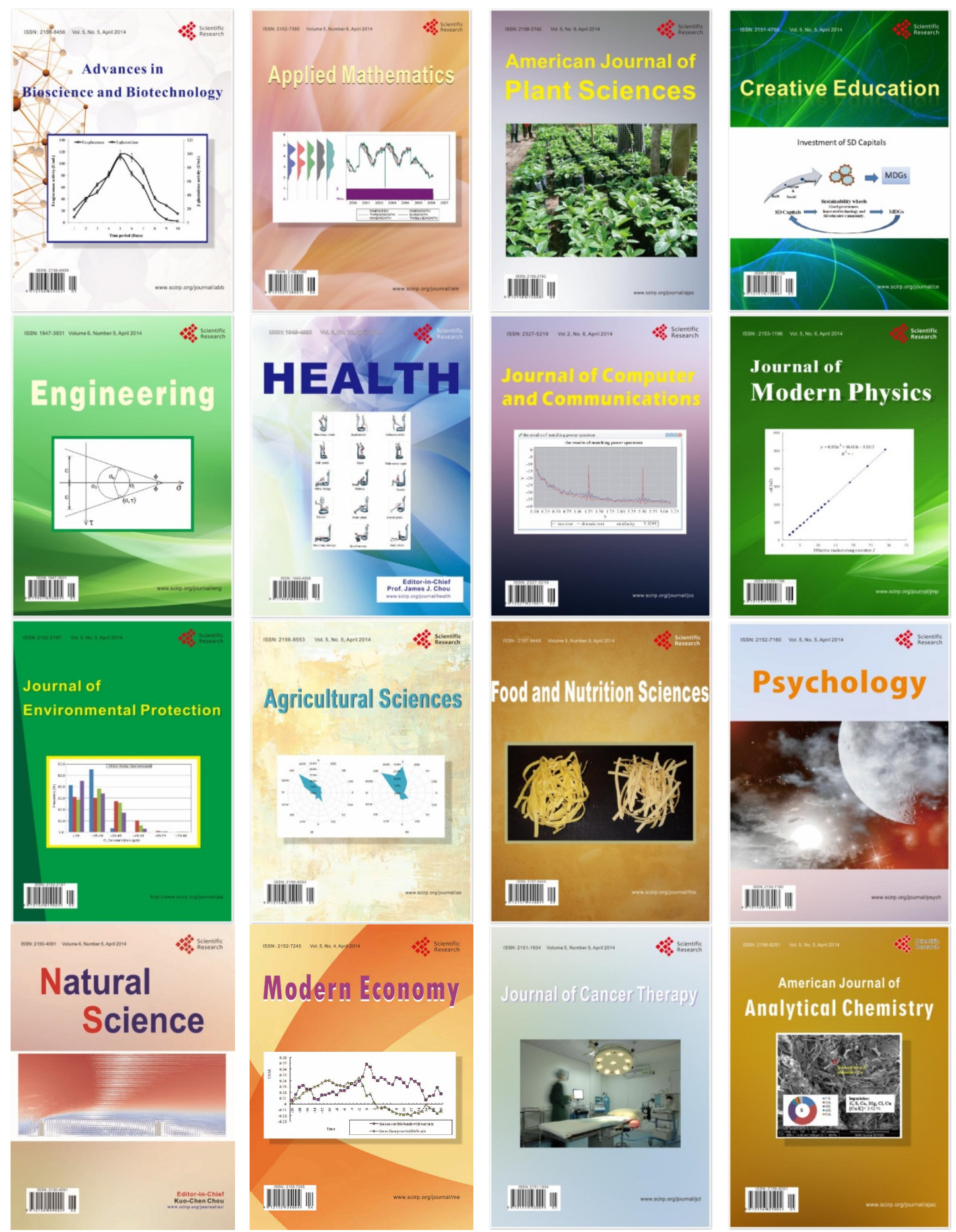